\title{
除草剤フルアジホップの開発
}

\author{
芳賀隆弘, 藤川敢市, 坂下信行, 西山隆三
}

石原産業株式会社中央研究所

\section{Development of a New Herbicide, Fluazifop-butyl}

\author{
Takahiro Haga, Kan-ichi Fujıkawa, Nobuyuki Sakashita \\ and Ryuzo NishiYama
}

Central Research Labovatory, Ishihara Sangyo Kaisha, Ltd., Nishishibukawa-cho, Kusatsu 525, Japan

\begin{abstract}
Since the invention of phenoxyacetic acid herbicides with clear activity on broad-leaf plants, the development of a herbicide with reverse selectivity has been a long-pending problem from the practical viewpoint of removing grasses from broad-leaf crops. Based on the results of the long-term studies to improve the unfavorable characters of diphenyl ether herbicides, the authors have successfully developed fluazifop which is capable of killing grasses, including perennials, without damaging broad-leaf crops. Since diphenyl ether herbicides selected as a lead-compound do not translocate in plants but kill only the tissues directly exposed to the herbicides, an oxyalkanoate side-chain characteristic to the phenoxyacetic acid auxin herbicides, which are able to translocate in plant tissues, was introduced to the $3^{\prime}$-position adjacent to the nitro group on the diphenyl ether structure. Thus-prepared esters improved the translocation but not satisfactorily enough for the practical use. Therefore, the following attempts were made for optimization: 1) introduction of a trifluoromethyl group as a substituent on the 4-position, 2) alteration of one of the benzene rings to a pyridine nucleus, 3) elimination of the nitro group on the 4-position which had been regarded indispensable, 4) migration of oxyalkanoate on the 3-position to the 4-position, 5) selection of lactate out of alkanoates to obtain optimum herbicidal activity, and 6) modification of an ester moiety. Thus-prepared fluazifop-butyl, endowed with selectivity of killing grass weeds without damaging broad-leaf crops and with excellent translocatability in plant tissues to the extent of killing the subterranean stems of perennial grasses even in case of foliar treatment, is now marketed for the use in cotton, soybean and beet fields. Structure-activity relationship studies on fluazifop and its related analogs indicated that the trifluoromethylpyridinyloxy group played an important role in the hydrophobicity and total molecule structure to obtain optimum herbicidal activity and in enhancing the systemic activity to let the molecule reach a target organ through plant tissues.
\end{abstract}

\section{は じめに}

フルアジホップ ブチル 1a ${ }^{1)}$ はわが国をはじめとし， 欧米等約 40 か国で農薬登録がなされ，棉，大豆，ビート
等の広葉作物栽培畑の一年生扣よび多年生のイネ科雑草 の防除に使用されている, 新しいタイプの除草剤である. 近年, 農薬等の生理活性物質の開発のための構造活性 相関の研究において, 定量的なアプローチが盛んに利用 
されている. しかし 1960 年代の新薬の開発研究におい ては，この手法はまだ一般的ではなく，試行錯誤による 研究が中心であった．したがって，既存の生理活性物質 の母核を化学修飾するには適切なハイポセシスに従って 研究を展開するのが能率の上からも，また得られたデー タを整理, 解析する点からも有利であった. 1965 年, 著 者らは水田拉よび畑作用除草剤として広く使用されてい たジフェニルェーテル系薬剤をリード化合物として選 び，その欠点である接触型の作用性を改良するために， 種々ハイポセシスに従って開発研究を行なった. 植物体 内移行性に優れているフェノキシ酢酸系のオーキシン型 除草剂に特有なオキシアルカン酸側鎖を, ジフェニルェ ーテル構造に置換基として導入したところ，予期したよ らに移行性が向上寸るといら知見が得られる一方で，こ れらはジフェニルェーテル系除草剂とはまるで異なる作 用性, 殺草スペクトル等を示したので, さらに optimizationを重祇，1977 年に至ってこの系統の化合物の中か らとくに優れたフルアジホップ ブチル 1a 〔 $n$-butyl 2-[4(5 - trifluoromethylpyridin-2-yloxy) phenoxy] propanoate, Fusilade®，Hache Uno Super®，ワンサイド®]を選抜 した.

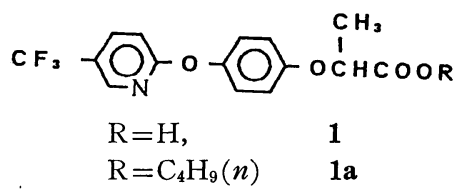

このようにして見いだした $1 \mathrm{a}$ について社内での本格 的な研究開発に入ると同時に, 1978 年からイギリスの ICI 社と共同で世界的に実用性評価試験を開始し, 海外 では 1980 年から, 国内では 1986 年に本剤の農薬登録が 認可され上市するに至った，ここではその研究の経緯， 作用特性, 作用機作, 構造活性相関, 合成法についてそ の概要を述べる.

\section{研究の 経 緯}

ジフェニルェーテル系除草剤に関する著者らの 1960 年代の研究により, nitrofen 2 の塩素置換されたベンゼ ン環をピリジン環に置き換えた化合物, Code X-542 3 は，処理した植物に 2 にはみられないクロロシスを発現 することが見いだされた2).

その後, 著者らにより水田除草剂 chlomethoxyfen 4 が開発され3)，その azalogue (Code R-60 5) もやはりク ロロシスを呈することが判明したが, 除草活性（接触作 用）は親化合物に比べ若干劣ることも確認された4).

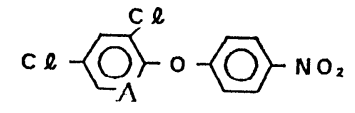

$\begin{array}{ll}\mathrm{A}=\mathrm{CH}, \text { nitrofen } & \mathbf{2} \\ \mathrm{A}=\mathrm{N}, \mathrm{X}-542 & \mathbf{3}\end{array}$

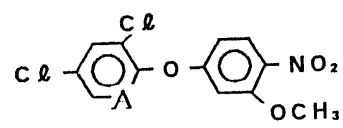

$\mathrm{A}=\mathrm{CH}$, chlomethoxyfen 4

$\mathrm{A}=\mathrm{N}, \mathrm{R}-60$

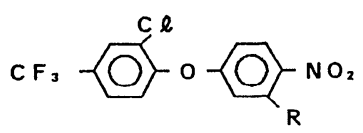

$\begin{array}{ll}\mathrm{R}=\mathrm{H}, \mathrm{IX}-13 & \mathbf{6} \\ \mathrm{R}=\mathrm{OC}_{2} \mathrm{H}_{5}, \mathrm{X}-1428 & \mathbf{7}\end{array}$

また，それまでに開発された除草剤に共通していた 2 位と 4 位の 2 個の塩素原子のうち，4 位の塩素をトリフ ルオロメチル基に置換した化合物 $\mathbf{6}$ 打よび $\mathbf{7}$ はジクロロ 化合物をはるかに凌駕する強力な除草活性を有するとい ら知見も得られた ${ }^{5)}$.

Nitrofen 2 と chlomethoxyfen 4 は抢もに水田用の除 草㓮として使用されているが, 光の存在下でのみ除草活 性を発現する等, 作用メカニズムは同じであり, また作 用性はともに接触型である. したがって, 植物体内移行 性が小さく薬剤が接触してない地下部等の組織を破壊で きないため, 多年生草種等の完全防除は困難であった. 著者らはジフェニルェーテル系除草剤の改良のために, 移行性を付与する目的で種々の化合物を合成したが，そ の具体的なアイデアとして体内移行性に優れているオー キシン型のフェノキシ酢酸系除草剤に特有なオキシアル カン酸基の導入を行なった. ただし前提条件として従来 のジフェニルェーテル系除草剛の 2 位, 4 位そして $4^{\prime}$ 位 の置換基は作用発現の必須置換基として残した. Table 1 に示すように $3^{\prime}$ 位にオキシプロピオン酸エステルを 置換した化合物は, 移行能力を有する最初のジフェニル エーテルとして画期的ではあったが，実用的な見地から は移行能力自体が不十分であった。

この発見に勇気づけられて試みた次のハイポセシス は, 今まで除草活性発現には必須と思われていた $4^{\prime}$ 位 の強い電子吸引基の代わりに, オキシアルカン酸基を導 入することであった. こうして作られた SL-502 8 は従 来のジフェニルェーテル系除草剤とはまったく異なった 作用性を示した ${ }^{6)}$. 寸なわち, 強力な茎葉処理力に加兄 てイネ科植物には強く作用するが，広葉植物にはほとん 
Table 1 Herbicidal activity and translocatability of diphenyl ether compounds with foliar application.

\begin{tabular}{|c|c|c|c|c|}
\hline & $-0-\underbrace{\mathrm{C}_{3^{\prime}}^{4^{\prime}}}_{2^{\prime} \quad \mathrm{Y}}$ & & $\begin{array}{c}\text { Herbicidal } \\
\text { activity }\end{array}$ & Translocatability \\
\hline $\mathrm{X}$ & $\mathrm{Y}$ & $Z$ & & \\
\hline $\mathrm{Cl}$ & $-\mathrm{COOH}$ & $\mathrm{NO}_{2}$ & B & 一 \\
\hline $\mathrm{CF}_{3}$ & $-\mathrm{COOH}$ & $\mathrm{NO}_{2}$ & A & - \\
\hline $\mathrm{CF}_{3}$ & $\begin{array}{c}\mathrm{CH}_{3} \\
-\mathrm{OCHCO}_{2} \mathrm{CH}_{3}\end{array}$ & $\mathrm{NO}_{2}$ & A & $\dagger \sim \dagger \dagger$ \\
\hline $\mathrm{CF}_{3}$ & $\begin{array}{c}\mathrm{CH}_{3} \\
-\mathrm{OCHCO}_{2} \mathrm{CH}_{3}\end{array}$ & $\mathrm{CN}$ & $\mathrm{A}$ & $\dagger \sim \dagger \dagger$ \\
\hline
\end{tabular}

Herbicidal activity on Xanthium pensylvanicum WALLR. (20 DAT)

A: complete kill $\sim \mathrm{D}$ : no effect.

Translocatability in Solidago altissima L. (60 DAT)

$+\dagger+$ : high - : null.

ぞ影響を与えないという明確な選択性が確認された。た だし，薬物の 植物体内移行の点では今一歩の 感があっ た.

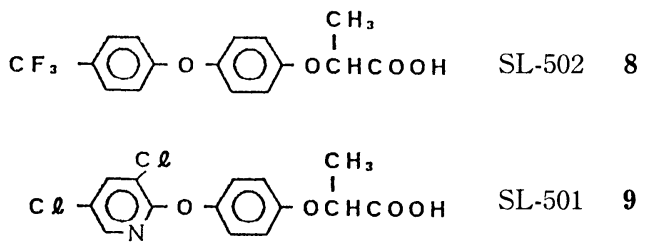

この段階において，当然の手順として第 1 のハイポセ シスを組み合わせて合成された SL-501 97) は，8 よりも 体内移行性は改良されていた。さらに研究を進めて見い だされたフルアジホップ 11) は驚くべきことに強力な除 草活性と明確な選択性をとのまま残し，さらに優れた移 行能力をも具備していることが判明した．すなわち，茥 葉に処理された 1 は植物体内を下方に移行し除草効力を 発揮する．このことは多年生の強害イネ科雑草をも枯死 させる能力を有する画期的な除草剤の発明に到達したこ とを意味する。

\section{作 用 特 性}

昨今の除草剂は性能が著しく高度化しており，今後開 発される茎葉処理剤は活性はもとより高度な選択性, 植 物体内移行性，あるいは耐雨性等の諸性質が不可欠とい われている. フルアジホップブチル $1 \mathrm{a}$ は，土塨処理 および茎葉処理活性を兼ね備えているが，後者が前者を 上回るので最も合理的な処理法は生育期に打ける茎葉処
理である8). したがって, $1 \mathbf{a}$ が前記諸性質を有するか否 かは，開発上重要なポイントである，1a の選択性を知 るために各種植物に対する感受性を調べた結果を Table 2 に示した. ほとんどのイネ科植物は $0.25 \mathrm{~kg} / \mathrm{ha}$ で完全 枯死し，一般に薬剤に対する抵抗性が強いといわれてい るススキ，チガヤでも $1.0 \mathrm{~kg} / \mathrm{ha}$ でほぼ枯死に至る.一 方, 双子葉植物およびカヤッリグサ科やツユクサ科等, イネ科植物以外の単子葉植物は $1.0 \mathrm{~kg} / \mathrm{ha}$ ではまったく 反応しない，このように，1a はイネ科植物のみにさわ めて明確な選択的除草活性を有するが，実用場面では作 物とイネ科雑草間との選択性の幅が問題となるため，雑 草防除に必要な最低薬量と作物に対する薬害の許容限界 薬量から安全倍率を算出して，選択性幅の目安とした (Table 3). 1a に対して抵抗性であるワタの場合は, メ ヒシバ間で 40 倍，ノビェ間とでは 80 倍に達する． 1a に比較的感受性のビートやヒマワリでもメヒシバ間で 25 倍の安全性の幅が認められている. 多年生草種と作 物間の安全倍率は一年生草種の場合より相対的に小さ く，多年生雑草がより防除しにくいことを示している.

しかし，多年生雑草のうち最も抵抗性のシバムギと感受 性のビート間でも 8 倍の安全性を有しており，1a は広 葉作物栽培畑のイネ科雑草防除剤として薬害の心配のな い, 適用性の高い薬剤といえる。

世界の主要畑作地では多年生イネ科雑草による被害を 受けている地帯が多く9)，これらは既往の土壤処理剤で は防除が困難なため，重大な問題となっている．多年生 草種は地下部に栄養繁殖器官をもっているので, これの 完全防除のためには地上部はもちろんのこと，地下部ま 
Table 2 Herbicidal spectrum of fluazifop-butyl with foliar application.

\begin{tabular}{|c|c|c|c|}
\hline \multirow{2}{*}{ Plants } & & \multicolumn{2}{|c|}{ Dosage (kg/ha) } \\
\hline & & 0.25 & 1.0 \\
\hline \multicolumn{4}{|l|}{ Monocotyledones } \\
\hline \multirow[t]{15}{*}{ Gramineae } & Echinochloa crus-galli (L.) BEAUv. & 10 & 10 \\
\hline & Lolium multiflorum LAM. & 10 & 10 \\
\hline & Avena fatua $\mathrm{L}$. & 10 & 10 \\
\hline & Eleusine indica (L.) GaERTn. & 10 & 10 \\
\hline & Alopecurus geniculatus L. & 10 & 10 \\
\hline & Setaria viridis (L.) Beauv. & 10 & 10 \\
\hline & Digitaria ciliaris (Retz.) Koel. & 10 & 10 \\
\hline & Cynodon dactylon (L.) PERs. & 9 & 10 \\
\hline & Agropyron repens (L.) BEAuv. & 9 & 10 \\
\hline & Miscanthus sinensis ANDERSS. & 4 & 9 \\
\hline & Imperata cylindrica (L.) BEAUv. & 3 & 9 \\
\hline & Oryza sativa $\mathrm{L}$ & 10 & 10 \\
\hline & Hordeum vulgave $\mathrm{L}$. & 10 & 10 \\
\hline & Triticum aestivum $\mathrm{L}$. & 10 & 10 \\
\hline & Zea mays L. & 10 & 10 \\
\hline \multirow[t]{2}{*}{ Cyperaceae } & Cyperus globosus AlL. & 1 & 1 \\
\hline & Cyperus rotundus $\mathrm{L}$. & 1 & 1 \\
\hline Commelinaceae & Commelina communis L. & 1 & 1 \\
\hline Liliaceae & Allium cepa L. & 1 & 1 \\
\hline Araceae & Colocasia esculeuta Scнотт. & 1 & 1 \\
\hline \multicolumn{4}{|l|}{ Dicotyledones } \\
\hline \multirow[t]{2}{*}{ Compositae } & Xanthium pensylvanicum L. & 1 & 1 \\
\hline & Helianthus annuus L. & 1 & 2 \\
\hline \multirow[t]{2}{*}{ Solanaceae } & Lycopersicum esculentum MiLL. & 1 & 1 \\
\hline & Solunum tuberosum L. & 1 & 1 \\
\hline \multirow[t]{3}{*}{ Leguminosae } & Glycine max MERR. & 1 & 1 \\
\hline & Vigna angularis & 1 & 1 \\
\hline & Arachis hypogaea $\mathrm{L}$. & 1 & 1 \\
\hline Rosaceae & Malus pumila MiLL. & 1 & 1 \\
\hline Cruciferae & Brassica napus L. & 1 & 1 \\
\hline \multirow[t]{2}{*}{ Chenopodiaceae } & Chenopodium album L. & 1 & 1 \\
\hline & Beta vulgaris $\mathrm{L}$. & 1 & 1 \\
\hline Cucurbitaceae & Cucumis sativus L. & 1 & 2 \\
\hline Malvaceae & Gossypium spp. & 1 & 1 \\
\hline Rutaceae & Citrus unshiu MARCOVICH & 1 & 1 \\
\hline \multicolumn{4}{|l|}{ Pteridophyte } \\
\hline Pteridaceae & Pteridium aqulinum (L.) KuнN. & 1 & 1 \\
\hline Osmundaceae & Osmunda japonica THUNB. & 1 & 1 \\
\hline Equisetaceae & Equisetum avvenuse L. & 1 & 1 \\
\hline
\end{tabular}

Phytotoxicity; 1: no effect $\sim 10$ : complete kill.

で薬剤が移行する必要がある. 1a は Table 4 に示した ように，地下茎からの再生抑制力もきわめて高く，優れ た効力を有している．これら植物体内移行能力をギョウ ギシバの匍甸茥を用いて調べた結果は Table 5 に示す と扣りである。1a は処理部はもちろんのこと，匍匐茎 の全節位からの萌芽を完全に抑制し, 最終的に個体全体 を枯殺した１１ａ良好な移行性は，下位節の萌芽をま
ったく抑制することのできない同系統の ジクロホップ メチル10 と此べると明らかである.

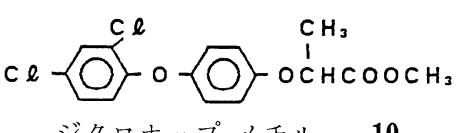

ジクロホップメチル 10

一方，非選択性茎葉処理剂の glyphosate 〔N-(phos- 
phonomethyl)glycine, Monsanto 社]も強い移行性を示 すが，完全な萌芽抑制は処理部から4節までに止まって いる. また paraquat $\left\lceil 1,1^{\prime}\right.$-dimethyl-4,4'-bipyridylium dichloride, ICI 社]は，隣接する節位からの萌芽さえも抑 えることができない.このように 1a の多年生イネ科雑 草に詨する高い防除効果は, その強力な移行性に起因し

Table 3 Selectivity of fluazifop-butyl between gramineous weeds and broadleaved crops with foliar application.

\begin{tabular}{ccccc}
\hline $\begin{array}{c}\text { Gramineous } \\
\text { weeds } \\
\text { as standard }\end{array}$ & \multicolumn{4}{c}{ Safety ratio } \\
\cline { 2 - 5 } & $\begin{array}{c}\text { Soy- } \\
\text { bean }\end{array}$ & Cotton & $\begin{array}{c}\text { Sugar } \\
\text { beet }\end{array}$ & $\begin{array}{c}\text { Sun- } \\
\text { flower }\end{array}$ \\
\hline $\begin{array}{c}\text { Crabgrass } \\
\text { (3L stage) }\end{array}$ & 33 & 42 & 25 & 25 \\
$\begin{array}{c}\text { Barnyardgrass } \\
\text { (3L stage) }\end{array}$ & 67 & 83 & 50 & 50 \\
$\begin{array}{c}\text { Quackgrass } \\
\text { (6L stage) }\end{array}$ & 10 & 13 & 8 & 8 \\
$\begin{array}{c}\text { Johnsongrass } \\
\text { (5L stage) }\end{array}$ & 16 & 20 & 12 & 12 \\
Bermudagrass & 33 & 42 & 25 & 25 \\
\hline Safety ratio $=\frac{\text { (Dosage (kg/ha) which gives } 5 \%}{\text { growth inhibition in crop }}$ & $\begin{array}{l}\text { Dosage (kg/ha) which gives } 95 \% \\
\text { growth inhibition in weed }\end{array}$ \\
\hline
\end{tabular}

ていることが判明した。

植物体内への吸収速度は実用場面では薬剤の耐雨性に 影響を与える 重要な要因である１１ａ吸収速度を調べ るために，茎葉処理したジョンソングラスの茎葉部を一 定時間ごとに切除し, その後の地下茎からの再生程度を 調べた (Table 6). 1a の処理後 6 時間目切除における再 生抑止力は $70 \%$ で，12 時間後では完全な抑制が認めら れた. 一方, glyphosate は 12 時間後切除でも $50 \%$ の抑 止力を示すにすぎず，1a は短時間に植物体へ吸収され 移行していることが明らかである. 次に実際に人工降雨 を与えた実験結果を Table 7 に示した. 1a は処理後 6 時間を経過すれば降雨の影響を受けず，速やかな浸透性 による 1a の耐雨力が確認された.

一般に茎葉処理剂は, 散布むらや降雨等によって効果 が変動する場合があるが，1a のように強力な浸透移行 性を有する薬剤は，このような実際の使用条件下でも安 定した除草効果が期待できる.

\section{作 用 機 作}

イネ科植物にフルアジホップ 1 を茥葉処理した場合, まず茎葉部の生長停止が妈理後 $2 \sim 3$ 日目から肉眼で観 察される．展開の止まった新葉は褪色し，続いて生長点 を含めた低節部の壊死，新葉・古葉の壊死を経て植物全 体の完全枯死に至る。これに要する日数は草種や気象条

Table 4 Herbicidal activities of fluazifop-butyl against perennial gramineous weeds with foliar application.

\begin{tabular}{|c|c|c|c|c|c|c|c|c|c|}
\hline \multirow[t]{2}{*}{ Herbicides } & \multirow[t]{2}{*}{$\begin{array}{l}\text { Dosage } \\
\text { (kg/ha) }\end{array}$} & \multicolumn{2}{|c|}{$\begin{array}{l}\text { Sorghum } \\
\text { halepens (L.) } \\
\text { (5-6L stage) }\end{array}$} & \multicolumn{2}{|c|}{$\begin{array}{l}\text { Agropyron } \\
\text { repens (L.) } \\
(20 \mathrm{~cm})\end{array}$} & \multicolumn{2}{|c|}{$\begin{array}{c}\text { Imperata } \\
\text { cylindrica (L.) } \\
(30 \mathrm{~cm})\end{array}$} & \multicolumn{2}{|c|}{$\begin{array}{l}\text { Miscanthus } \\
\text { sinensis } \\
(50-60 \mathrm{~cm})\end{array}$} \\
\hline & & $\mathrm{T}$ & $\mathrm{R}$ & $\mathrm{T}$ & $\mathrm{R}$ & $\mathrm{T}$ & $\mathrm{R}$ & $\mathrm{T}$ & $\mathrm{R}$ \\
\hline \multirow{3}{*}{ Fluazifop-butyl } & 0.5 & 10 & - & 10 & - & 6 & $H$ & 7 & + \\
\hline & 1.25 & 10 & - & 10 & - & 9 & + & 9 & + \\
\hline & 2.5 & 10 & - & 10 & - & 10 & - & 10 & 一 \\
\hline \multirow{3}{*}{ Diclofop-methyl } & 0.5 & 1 & 世 & 1 & H & 1 & \# & 1 & H \\
\hline & 1.25 & 1 & 世 & 1 & H & 1 & 世 & 1 & 世 \\
\hline & 2.5 & 2 & 世 & 1 & W & 1 & W & 1 & H \\
\hline \multirow{3}{*}{ Glyphosate } & 0.5 & 4 & W & 5 & H & 3 & 卅 & 2 & H \\
\hline & 1.25 & 6 & W & 9 & + & & & & \\
\hline & 2.5 & 10 & - & 10 & 一 & 7 & H & 7 & m \\
\hline \multirow{3}{*}{ Paraquat } & 0.5 & 1 & 世 & 1 & H & 1 & 世 & 1 & m \\
\hline & 1.25 & 1 & W & 4 & H & 1 & \# & 1 & H \\
\hline & 2.5 & 2 & m & 6 & \# & 2 & W & 2 & m \\
\hline
\end{tabular}

T; herbicidal activity for aerial part (assessed 30 days after treatment), 1: no effect $\sim 10$ : complete kill. $\mathrm{R}$; degree of regrowth (assessed 60 days after treatment), - : no regrowth $\sim$ H: equivalent to untreated. 
Table 5 Translocatability of fluazifop-butyl in Bermudagrass (Cynodon dactylon (L.) PERS.) stolon examined by dipping application of top of the plant.

\begin{tabular}{|c|c|c|c|c|c|c|c|c|c|c|c|c|c|c|}
\hline \multirow{3}{*}{ Herbicides } & \multirow{3}{*}{$\begin{array}{l}\text { Damage on } \\
\text { top portion }\end{array}$} & \multicolumn{12}{|c|}{ Degree of sprout regrowth at untreated nodes } & \multirow{3}{*}{$\begin{array}{l}\text { Degree of } \\
\text { sprout regrowth } \\
\text { at stolon base }\end{array}$} \\
\hline & & \multicolumn{12}{|c|}{ Node number from top treated portion } & \\
\hline & & 1 & 2 & 3 & 4 & 5 & 6 & 7 & 8 & 9 & 10 & 11 & 12 & \\
\hline Fluazifop-butyl & 10 & - & - & - & - & - & - & - & - & - & - & - & - & + \\
\hline Diclofop-methyl & 4 & 世 & m & H & 册 & 卅 & H & 卅 & H & H & H & H & H & \# \\
\hline Glyphosate & 7 & - & - & - & - & + & + & + & + & + & + & + & + & $+\sim H$ \\
\hline Paraquat & 10 & 世 & 世 & H & W & W & H & 世 & \# & H & W & W & 世 & 世 \\
\hline
\end{tabular}

Concentration of herbicide solution; 2000 ppm for all herbicides.

Damage on top portion; 1: no effect 10: complete kill.

Degree of sprout regrowth; - : no regrowth HI: equivalent to untreated.

Method of treatment;

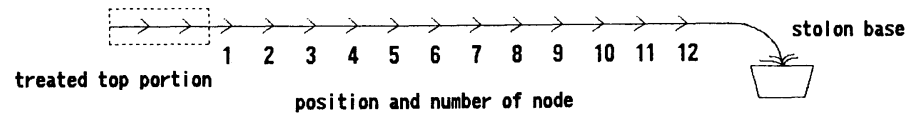

Table 6 Test of absorption velocity of fluazifop-butyl examined by excising the aerial part treated.

\begin{tabular}{|c|c|c|c|c|c|c|}
\hline \multirow{3}{*}{ Herbicides } & \multirow{3}{*}{$\begin{array}{l}\text { Dosage } \\
(\mathrm{kg} / \mathrm{ha})\end{array}$} & \multicolumn{3}{|c|}{ Excised } & \multicolumn{2}{|c|}{ Not excised } \\
\hline & & \multicolumn{3}{|c|}{$\begin{array}{l}\text { Inhibition of regrowth } \\
\text { Excised time (hr after treatment) }\end{array}$} & \multirow{2}{*}{$\begin{array}{l}\text { Damage of } \\
\text { aerial part }\end{array}$} & \multirow{2}{*}{$\begin{array}{l}\text { Inhibition } \\
\text { of regrowth }\end{array}$} \\
\hline & & 1 & 6 & 12 & & \\
\hline Fluazifop-butyl & 0.5 & 1 & 7 & 10 & 10 & 10 \\
\hline Glyphosate & 1.5 & 1 & 1 & 5 & 10 & 10 \\
\hline
\end{tabular}

Test plant; Johnsongrass (5-6 leaf stage).

Inhibition of regrowth or damage; 1: no effect 10 : complete inhibition or kill.

Table 7 Effect of rain on post-emergence activity of fluazifop-butyl.

\begin{tabular}{|c|c|c|c|c|c|c|c|c|c|}
\hline \multirow{3}{*}{ Herbicides } & \multirow{3}{*}{$\begin{array}{l}\text { Dosage } \\
(\mathrm{kg} / \mathrm{ha})\end{array}$} & \multicolumn{6}{|c|}{$\begin{array}{l}\text { Starting time of artificial rain } \\
\text { (hr after treatment) }\end{array}$} & \multirow{2}{*}{\multicolumn{2}{|c|}{ No rain }} \\
\hline & & \multicolumn{2}{|c|}{1} & \multicolumn{2}{|c|}{6} & \multicolumn{2}{|c|}{24} & & \\
\hline & & $\mathrm{T}$ & $\mathrm{R}$ & $\mathrm{T}$ & $\mathrm{R}$ & $\mathrm{T}$ & $\mathrm{R}$ & $\mathrm{T}$ & $\mathrm{R}$ \\
\hline Fluazifop-butyl & 0.5 & 8 & 一 & 9 & - & 10 & 一 & 10 & - \\
\hline Glyphosate & 1.5 & 3 & HW & 5 & H & 8 & H & 10 & - \\
\hline
\end{tabular}

Test plant ; Johnsongrass (6-7 leaf stage).

Rain fall ; $40 \mathrm{~mm}$ (artificial rain).

$\mathrm{T}$; Damage of aerial part 1: no effect 10: complete kill.

$\mathrm{R}$; Regrowth from subterranean part - : no regrowth $\sim$ Wl: equivalent to untreated.

件等にもよるが，2 ないし 4 週間であり，本剤による完 全枯殺は遅効的である.

まず，上述のイネ科植物に対して観察される本剤に特
徵的な速やかな生育停止作用の解析のために，植物細胞 の生長と分裂の二過程に及ぼす本薬剤の影響を調べた. イネ科植物としてトウモロコシ，非イネ科植物として大 

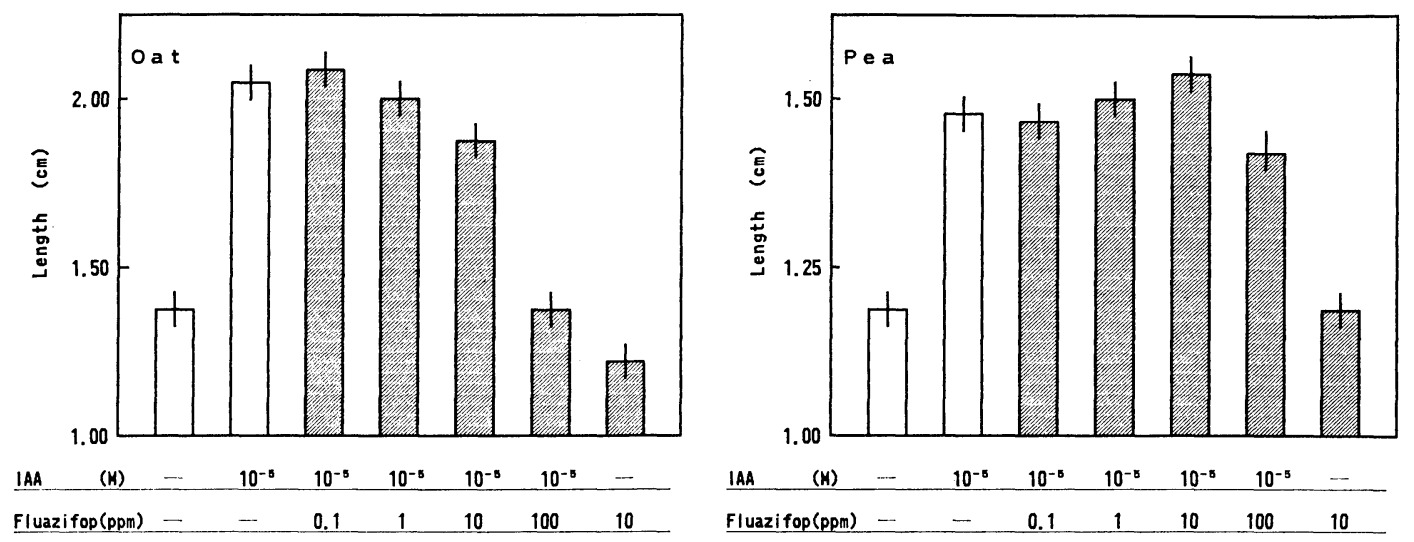

Fluazifop(ppm) - $\quad-\quad 0.1 \quad 1 \quad 10 \quad 100 \quad 10$

Fig. 1 Effect of fluazifop on the elongation of oat coleoptile and pea epicotile segments in the presence or absence of exogenous IAA.

The lengths of the 20 segments each were measured after an incubation period of $20 \mathrm{hr}$ in the dark. The error bars are the standard deviation of the means.

Table 8 Effect of root-applied fluazifop on the mitotic index in root tips of maize and soybean.

\begin{tabular}{lrcc}
\hline \multirow{2}{*}{$\begin{array}{c}\text { Treatment } \\
\text { fluazifop }(\mathrm{ppm})\end{array}$} & \multicolumn{2}{c}{ Mitotic index (\%) } \\
\cline { 2 - 4 } & 0 & $6.9 \pm 0.3$ & $5.5 \pm 0.6$ \\
\multirow{2}{*}{ Maize } & 1 & $2.6 \pm 0.4$ & $1.9 \pm 0.5$ \\
& 10 & $1.8 \pm 0.2$ & $1.1 \pm 0.2$ \\
\hline \multirow{3}{*}{ Soybean } & 0 & $7.1 \pm 0.2$ & $6.6 \pm 0.7$ \\
& 1 & $7.2 \pm 0.8$ & $6.4 \pm 0.5$ \\
& 10 & $7.4 \pm 0.2$ & $6.3 \pm 0.4$ \\
\hline
\end{tabular}

The values are expressed as means \pm S.D.

豆を用い，各植物の根端組織の細胞分裂に及ぼす本剤の 効果をみると (Table 8)，トウモロコシでは $1 \mathrm{ppm}$ の低 濃度で 1 日以内に，根端細胞の分裂指数を大きく低下さ せることが明らかとなった，一方，大豆では $10 \mathrm{ppm}$ 処 理の 2 日後でも何ら影響が認められず，本剂がイネ科植 物の細胞分裂を特異的に阻害することを示している。 む ら一つの過程である伸長生長に関しては, 感受性植物の エン麦 (Avena sativa L.) から調整した子葉䩗切片を, フルアジホップ 1 を含む薬液中で 20 時間インキュベー トし，伸長生長に対する阻害を調べた (Fig. 1)。その結 果オーキシン (IAA) を含む場合も含まない場合も，1 は それぞれの対照に比して $10 \mathrm{ppm}$ の濃度で 30 50\% の 阻害を示し，イネ科植物の伸長生長を阻害することが明 らかとなった．一方，エンドゥ上肧軸切片を用いた同様 の実験では，1にはこのような阻害は認められず，本剤

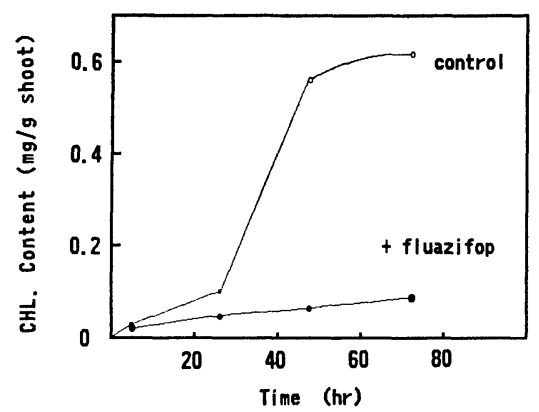

Fig. 2 Effect of root-applied fluazifop on the greening process of etiolated maize seedling.

の伸長生長阻害は, 感受性植物の久に短時間内に発現し た．したがって，本薬剤のイネ科植物に対する選択的生 育停止作用は, 細胞分裂と細胞生長の両過程を 1 日以内 に大きく阻害することによるものと考兄られた．

細胞の分裂や伸長生長は, 細胞内代謝に基づくので, 本剤によって何らかの細胞内代謝の質的，量的変動が引 き起こされているものと予想される. 実際, 本薬剤の処 理によりクロロフィル生合成の阻害 (Fig. 2), 可溶性糖 質含量の増加, 遊離アミノ酸含量の 異常な蓄積 (Table 9）等，代謝物の生合成や含量に大きな変動のあること が明らかとなった ${ }^{10)}$. しかし，いずれの変動も植物体の 損傷に伴った遅効的な作用であり，二次的な効果と考兄 られた。

より短期の作用を追求するために，基本的な代謝であ る DNA，タンパク質，脂質の生合成に及ぼすフルアジ 
ホップ1の影響を，トレーサー実験によって検討した。 感受性植物において，いずれの生合成も 24 時間後には 見かけ上大きく阻害されたが (Table 10)，DNA，タン パク質に関しては生合成前駆体の取り込み阻害と並行し た現象であったので，細胞膜の膜透過活性の低下に起因

Table 9 Effect of root-applied fluazifop on the content of free amino acids in leaf tissue of maize and soybean.

\begin{tabular}{|c|c|c|}
\hline \multirow[t]{2}{*}{ Amino acids } & \multicolumn{2}{|c|}{$\begin{array}{c}\text { Ratio of amino } \\
\text { acid content } \\
\text { (treatment/control) }\end{array}$} \\
\hline & $\begin{array}{c}\text { Soybean } \\
10 \mathrm{ppm}\end{array}$ & $\begin{array}{l}\text { Maize } \\
1 \mathrm{ppm}\end{array}$ \\
\hline Asp & 1.1 & 7.7 \\
\hline Thr + Ser & 0.9 & 27.9 \\
\hline Glu & 1.5 & 8.5 \\
\hline Pro & 一 & - \\
\hline Gly & 1.0 & 6.0 \\
\hline Ala & 1.2 & 14.4 \\
\hline Cys & - & - \\
\hline Val & 1.6 & 7.9 \\
\hline Met & - & - \\
\hline Ileu & 1.1 & 4.1 \\
\hline Leu & 1.1 & 1.9 \\
\hline Tyr & 0.9 & 10.5 \\
\hline Phe & 1.0 & 8.8 \\
\hline His & 0.4 & 14.5 \\
\hline Lys & 1.5 & 5.0 \\
\hline Arg & 4.0 & 6.0 \\
\hline Unidentified 1 & 1.1 & 17.6 \\
\hline Unidentified 2 & 1.1 & 1.2 \\
\hline Unidentified 3 & 1.0 & 16.2 \\
\hline
\end{tabular}

することが示唆された。しかし，脂質生合成の阻害に関 しては (Fig. 3)，その阻害が処理 4 時間後の短時間内に 認められ，また膜透過活性の低下よりも大きな阻害を示 したことよりフルアジホップ 1 の主要な作用点の一つと 考えられる ${ }^{11)}$. 脂質生合成に支障をきたした場合，膜の 構造と機能が損われ，細胞の分裂と生長がまず阻害され て生育が停止するものと考えられる，続いて上記のよう

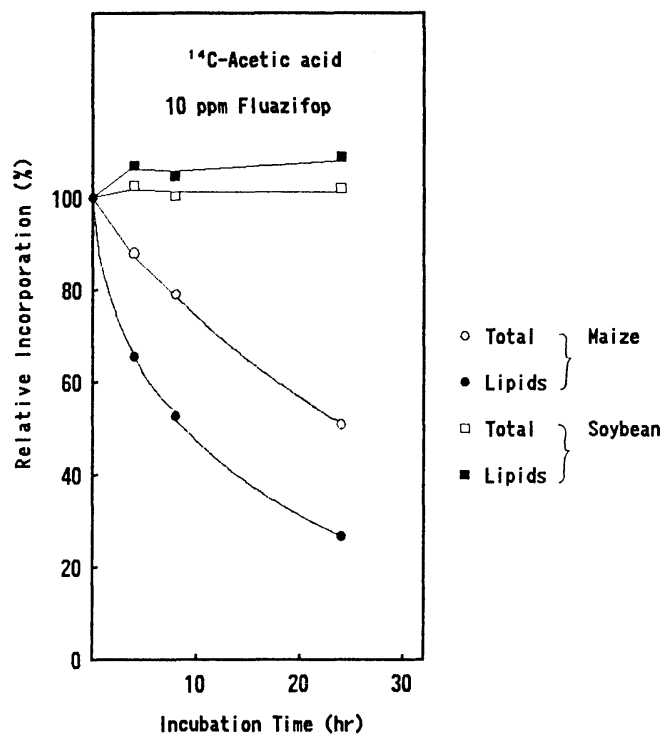

Fig. 3 Effect of fluazifop on total uptake and incorporation of ${ }^{14} \mathrm{C}$-acetic acid into lipids by root tip tissue of maize and soybean.

The root portion of maize and soybean seedling was treated with fluazifop for each sampling period. The root tips were cut from the main root and were incubated with ${ }^{14} \mathrm{C}$-acetic acid solution for $1 \mathrm{hr}$ followed by extraction of the tissue.

Table 10 Effect of root-applied fluazifop on the incorporation of ${ }^{3} \mathrm{H}$-thymidine, ${ }^{14} \mathrm{C}$-leucine, and ${ }^{14} \mathrm{C}$-acetic acid into DNA, protein, and lipids fraction, respectively, by root tip tissue of maize. The root portion of maize seedling was treated with $10 \mathrm{ppm}$ fluazifop solution for each sampling period. The root tips were cut from the main root and were incubated with labeled compounds for $1 \mathrm{hr}$ followed by extraction of the tissue.

\begin{tabular}{|c|c|c|c|c|c|c|}
\hline \multirow{3}{*}{ Treatment period } & \multicolumn{6}{|c|}{ Relative incorporation $(\%)$} \\
\hline & \multicolumn{2}{|c|}{${ }^{3} \mathrm{H}$-Thymidine } & \multicolumn{2}{|c|}{${ }^{14} \mathrm{C}$-Leucine } & \multicolumn{2}{|c|}{${ }^{14} \mathrm{C}$-Acetic acid } \\
\hline & Total & DNA frac. & Total & Protein frac. & Total & Lipids frac. \\
\hline $4 \mathrm{hr}$ & 95 & 102 & 100 & 98 & 88 & 66 \\
\hline $8 \mathrm{hr}$ & 78 & 76 & 81 & 78 & 79 & 52 \\
\hline $24 \mathrm{hr}$ & 54 & 43 & 49 & 40 & 54 & 28 \\
\hline
\end{tabular}


な二次的な代謝異常を起こし，徐々に枯死に至るもので あろら。

\section{構造活性相関研究}

フルアジホップ ブチル 1a の最適構造を確認するため に，除草活性と化学構造との相関関係について検討した 結果を述べる。

本系統薬剂の除草活性の評価基準を，一定時間後の， 一定の大きさのリスポンスを誘起させる化合物の濃度で
表わそうとすると，20\% 近くの実験誤差を伴うので， 多重回㷌分析の型で Hansch-Fujita 法を適用して, 本系 統薬剂の定量的構造活性相関 (QSAR) 解析を行なって も信頼度が低いと思われたので，本系統薬剤のスクリー ニング試験の評価結果をそのまま利用し，ピリジニルオ キシフェノキシプロパン酸誘導体の四つの部分構造につ いての置換基パターンの変化による除草活性について定 性的な解析を行なった ${ }^{12)}$. 除草活性は三葉期ヒエの茥葉 処理効果を，次表の評価基準に従って判定した.

Table 11 Herbicidal activity of carboxylic acid analogs of fluazifop-butyl 1a.

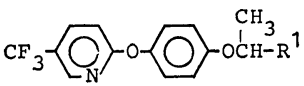

\begin{tabular}{|c|c|c|c|c|c|}
\hline Entry & $\mathrm{R}^{1}$ & $\begin{array}{l}\text { Herbicidal } \\
\text { activity }\end{array}$ & Entry & $\mathrm{R}^{1}$ & $\begin{array}{l}\text { Herbicidal } \\
\text { activity }\end{array}$ \\
\hline 1 & $-\mathrm{COOH}$ & B & & & \\
\hline 2 & $-\mathrm{COOCH}_{3}$ & A & 24 & $\begin{array}{c}-\mathrm{COOC}-\mathrm{C} \\
1 \\
\mathrm{CH}_{3}\end{array}$ & B \\
\hline 3 & $-\mathrm{COOC}_{2} \mathrm{H}_{5}$ & A & & & \\
\hline 4 & $-\operatorname{coOC}_{3} \mathrm{H}_{7}(\mathrm{n})$ & A & 25 & $-\mathrm{COOCH}_{2} \mathrm{CCl}_{3}$ & A \\
\hline 5 & $-\mathrm{COOC}_{3} \mathrm{H}_{7}(\mathrm{i})$ & A & 26 & $-\mathrm{COO}\left(\mathrm{CH}_{2}\right)_{2} \mathrm{CO}_{2} \mathrm{C}_{2} \mathrm{H}_{5}$ & B \\
\hline $\begin{array}{l}6 \\
7\end{array}$ & $\begin{array}{l}-\operatorname{cooc}_{4} \mathrm{H}_{9}(\mathrm{n}) \quad \underset{\sim}{1 \mathrm{a}} \\
-\operatorname{cooc}_{5} \mathrm{H}_{11}(\mathrm{n})\end{array}$ & $\begin{array}{l}\text { A } \\
\text { A }\end{array}$ & 27 & 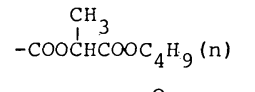 & A \\
\hline 8 & $-\operatorname{coOC}_{6} \mathrm{H}_{13}$ & A & 28 & $-\mathrm{COOCH}_{2} \mathrm{CH}-\mathrm{CH}_{2}$ & A \\
\hline 9 & $\begin{array}{c}-\mathrm{COOC}_{7} \mathrm{H}_{15} \\
\mathrm{C}_{7} \mathrm{H}_{5}\end{array}$ & A & 29 & (O) & B \\
\hline 10 & $-\mathrm{COOCH}-\mathrm{C}_{4} \mathrm{H}_{9}$ & B & 30 & $-\mathrm{CO}$ & B \\
\hline 11 & $-\mathrm{CoOC}_{8} \mathrm{H}_{17}$ & A & 31 & & B \\
\hline 12 & $\begin{array}{c}\mathrm{C}_{2} \mathrm{H}_{5} \\
-\mathrm{COOCH}-\mathrm{C}_{5} \mathrm{H} 11\end{array}$ & B & & & \\
\hline 13 & $-\mathrm{COOC}_{9} \mathrm{H}_{19}$ & B & 32 & $-\mathrm{CO}$ & B \\
\hline 14 & $-\operatorname{CoOC}_{10} \mathrm{H}_{21}$ & B & 33 & $-\mathrm{CONH}_{2}$ & D \\
\hline 15 & $-\mathrm{COOC}_{18} \mathrm{H}_{37}$ & c & 34 & $-\mathrm{CONHC}_{4} \mathrm{H}_{9}(\mathrm{n})$ & B \\
\hline 16 & $-\cos -\alpha$ & A & 35 & $-\mathrm{CONHCH}_{2} \mathrm{COOC}_{2} \mathrm{H}_{5}$ & B \\
\hline 17 & $-\cos -1$ & A & 36 & $-\mathrm{CONH}-\lfloor\underline{\mathrm{O}}$ & c \\
\hline 18 & $-\mathrm{COOCH}_{2} \mathrm{CH}_{2}-\mathrm{H}$ & A & 37 & $-\operatorname{CoNH}-\langle\mathrm{N}-$ & A \\
\hline 19 & $-\mathrm{COOCH}_{2} \mathrm{CH}=\mathrm{CH}_{2}$ & A & 38 & $-\mathrm{CONHSO}_{2} \mathrm{CH}_{3}$ & B \\
\hline 20 & $-\mathrm{COOCH}_{2} \mathrm{CH}=\mathrm{CHCH}_{3}$ & B & 39 & $-\mathrm{CSNH}_{2}$ & D \\
\hline 21 & $\begin{array}{c}\left(\mathrm{CH}_{2}\right)_{5} \mathrm{CH}_{3} \\
-\mathrm{COOCH}-\mathrm{CH}=\mathrm{CH}_{2}\end{array}$ & B & 40 & $-\mathrm{CN}$ & $\mathrm{D}$ \\
\hline 22 & $-\mathrm{COOCH}_{2} \mathrm{C} \equiv \mathrm{CH}$ & A & & & \\
\hline 23 & $\begin{array}{r}\mathrm{C}_{3} \mathrm{H}_{7}(\mathrm{n}) \\
-\mathrm{COOCH} . \mathrm{C} \equiv \mathrm{CH}\end{array}$ & A & 41 & & D \\
\hline
\end{tabular}




\begin{tabular}{cc}
\hline 評価基準 & 完全 $(100 \%)$ 枯殺濃度 $(\mathrm{ppm})$ \\
\hline $\mathrm{A}$ & $<100$ \\
$\mathrm{~B}$ & $100 \sim 500$ \\
$\mathrm{C}$ & $500 \sim 1000$ \\
$\mathrm{D}$ & $1000 \sim 2000$ \\
$\mathrm{E}$ & $>2000$ \\
\hline
\end{tabular}

\section{1. カルボン酸部分の変化と除草活性 (Table 11)}

フルアジホップ 1 の置換基パターンを維持しながら, そのカルボン酸部分のみを変化させて除草活性の変動を 調ベた. 41 種のカルボン酸誘導体のうち，A ランクの 高い活性を示す化合物はアルキルェステル (entry 2 9 および 11), 脂環式エステル（同 16 18），不飽和ェス テル（同 19，22 および 23)，置換アルキルェステル（同 25，27 打よび 28)，打よびピリジルアミド（同 37）の 19 種である.いずれる $\mathrm{R}^{1}$ 部分の炭素数が 9 以下と少な い.

Bランクの活性を示す化合物としては， $\mathrm{R}^{1}$ 部分の炭 素数が 19 の長鎖状アルキルェステル (entry 15) を除く すべてのエステル，遊離の酸 (同 1)，拉よび炭素数の少 ないアミド類（同 34，35 拉よび 38）があげられる，炭 素数が多くなるほど活性が弱く，また第 1 級から 2 級, 3 級と分岐するほど活性が落ちる傾向がある。

その他のアミド，チオアミド，ニトリル類は相対的に 活性が低い。

以上の結果から次の解釈が可能である.

1）広範囲の酸誘導体に除草活性が認められ，加水分 解されやすいと思われる誘導体ほど活性が高いことか ら，活性体は母核化合物の遊離酸であると考学られる。 この仮定はフルアジホップ ブチルが植物体内で速やか に加水分解されるという代謝研究の結果によって支持さ れる。

2) フルアジホップ (entry 1) の除草活性が，そのエ ステルよりも劣るのは, 遊離酸の植物体への取り込及が エステルのそれよりも低いためと思われる.

2. 脂肪族部分の变化と除草活性 (Table 12)

アルキレン結合 $\mathrm{R}^{2}$ を変化させると大幅な除草活性の 低下がみられ，フルアジホップ ェチル $1 \mathrm{~b}$ の部分構造 であるエチリデン結合 (entry 2), およびそのD型光学 異性体（同 4) のみが強い活性を示す．また，植物体内 で脂肪酸の $\beta$-酸化を受けて，プロパン酸を生成する可 能性のある entry 5 のペンタン酸, entry 8 の 2-ペンテ ン酸, および entry 10 の 3-オキソペンタン酸の 3 化合
Table 12 Herbicidal activity of the aliphatic chain analogs of fluazifop-ethyl $\mathbf{1 b}$.

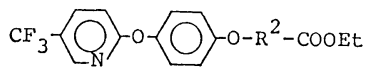

\begin{tabular}{|c|c|c|}
\hline Entry & $\mathrm{R}^{2}$ & $\begin{array}{c}\text { Herbicidal } \\
\text { activity }\end{array}$ \\
\hline 1 & $-\mathrm{CH}_{2}-$ & $\mathrm{E}$ \\
\hline 2 & $\begin{aligned} \mathrm{CH}_{3} & \\
-\mathrm{C} H- & \text { (racemic) } \mathbf{1 b} \\
\mathrm{CH}_{3} & \end{aligned}$ & A \\
\hline 3 & $\begin{array}{l}-\stackrel{1}{\mathrm{C}} \mathrm{H}-\quad \text { (L-) } \\
\mathrm{CH}_{3}\end{array}$ & $\mathrm{E}$ \\
\hline 4 & $\begin{array}{l}-\stackrel{1}{\mathrm{C}} \mathrm{H}-\quad \text { (D-) } \\
\mathrm{CH}_{3}\end{array}$ & A \\
\hline 5 & $\begin{array}{l}-\mathrm{CHCH}_{2} \mathrm{CH}_{2-} \\
\mathrm{CH}_{3}\end{array}$ & B \\
\hline 6 & $\begin{array}{l}-\stackrel{\text { C }}{\mathrm{L}}- \\
\stackrel{1}{\mathrm{C}} \mathrm{H}_{3} \\
\mathrm{CH}_{2} \mathrm{CH}_{3}\end{array}$ & $\mathrm{E}$ \\
\hline 7 & $\begin{array}{l}-{ }_{-}^{-} \mathrm{CH}_{-} \\
\mathrm{CH}_{3}\end{array}$ & $\mathrm{C}$ \\
\hline 8 & $\begin{array}{l}-\stackrel{\prime}{\mathrm{C}} \mathrm{HCH}=\mathrm{CH}- \\
\mathrm{CH}_{2}-\mathrm{OCH}_{3}\end{array}$ & B \\
\hline 9 & $-\stackrel{\prime}{\mathrm{C}} \mathrm{H}-$ & $\mathrm{E}$ \\
\hline 10 & $\begin{array}{l}\mathrm{CH}_{3} \\
\stackrel{\stackrel{\mathrm{C}}{\mathrm{C}} \mathrm{H}-\mathrm{C}-\mathrm{CH}_{2}-}{\stackrel{\mathrm{CH}_{2}}{\mathrm{O}}}\end{array}$ & B \\
\hline 11 & $\begin{array}{l}\mathrm{CH}_{3} \\
\stackrel{!}{\mathrm{C}}- \\
\stackrel{!}{\mathrm{C}} \mathrm{O}_{2} \mathrm{C}_{2} \mathrm{H}_{5}\end{array}$ & $\mathrm{D}$ \\
\hline 12 & $\begin{array}{c}\mathrm{CH}_{3} \\
\stackrel{1}{-}- \\
-\mathrm{C}- \\
\stackrel{1}{\mathrm{C}} \mathrm{l}\end{array}$ & C \\
\hline
\end{tabular}

物がフルアジホップエチル（同 2) に次ぐ除草活性を示 す.

3. ベンゼン環の置換基 $\mathrm{X}$ の変化と除草活性（Table 13)

置換基のもつ物性，大きさ等に関係なく，ベンゼン核 上のいかなる置換基も活性を大幅に低下させている，類 似した部分構造をもつ従来のフェノキシ酢酸系除草剤* では, フルアジホップ 1 に対応する 4-CPA 12 の 2 位に メチル基，または塩素原子を導入した MCP 13，また は2,4-D 14 が 12 よりも除草活性が高く, 本系統薬剂と は置換基効果が明らかに異なる。 
Table 13 Change of herbicidal activity by the modification of substituents $\mathrm{X}$ on benzene ring of fluazifop-ethyl $\mathbf{1 b}$.

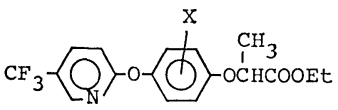

\begin{tabular}{|c|c|c|}
\hline Entry & $\mathrm{X}$ & $\begin{array}{c}\text { Herbicidal } \\
\text { activity }\end{array}$ \\
\hline $\mathbf{1}$ & $1 b$ & $\mathrm{~A}$ \\
\hline 2 & $3-\mathrm{CH}_{3}$ & $\mathrm{D}$ \\
\hline 3 & $2-\mathrm{CH}_{3}$ & $\mathrm{D}$ \\
\hline 4 & $3-\mathrm{Cl}$ & $\mathrm{E}$ \\
\hline 5 & $2-\mathrm{Cl}$ & $\mathrm{E}$ \\
\hline 6 & $2-\mathrm{Br}$ & $\mathrm{E}$ \\
\hline 7 & $2-\mathrm{OCH}_{3}$ & $\mathrm{E}$ \\
\hline
\end{tabular}

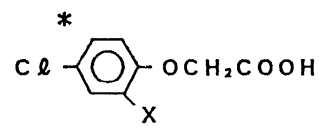

$$
\begin{array}{cll}
\mathrm{X}=\mathrm{H}, & 4-\mathrm{CPA} & \mathbf{1 2} \\
\mathrm{CH}_{3}, & \mathrm{MCP} & \mathbf{1 3} \\
\mathrm{Cl}, & 2,4-\mathrm{D} & \mathbf{1 4}
\end{array}
$$

4. ピリジン環の置換基 $\mathbf{Y}$ の変化と除草活性 (Table 14)

種々置換基パターンを変化させた 40 化合物のらち, 高い除草活性を示すものは 8 件である.これらの 8 化合 物はモノ置換体であれば 5 の位置に，ジ置換体であれば 3，5 の位置にと，すべて 5 位に置換基を有している. またBランクの 5 化合物についても同じことがいえるの で，ピリジン環の 5 位に位置特異性がある.

しかしながら， 5 位に強い電子吸引基のニトロ基 (entry 33)，電子供与基であるメチル基（同 11）や，メチ ルメルカプト基（同 37）を有する化合物拉よび無置換体 （同 1）がすべて除草効果を発現しないことから，電子 的な影響は除草活性発現のための重要な困子とはなって いない。高い除草活性を発現している置換基はハロゲ ントリフルオロメチル，またはジフルオロクロロメチ ル基であるので，適当な蹯水性のパラメータ $\pi$ を有する 置換基が活性発現に寄与しているように推測される.

さらに, Table 14 の化合物のらち, entry 18, 24 お よび 39 を除いた 37 化合物を対象にヒエに対する茎葉処 理効果 $L$ につい ALS 法を用いて構造活性相関式を求 めると式 (1) が得られた.

$$
\begin{aligned}
L= & 0.98 \pi-0.28 \pi^{2}-0.81 \mathrm{~B}_{4(\underline{3})}+1.06 \mathrm{~L}_{(\underline{5})} \\
& -1.07 \mathrm{~B}_{4(\underline{6})}-1.21 \\
N & =37, N_{\mathrm{mis}}=15(4), R_{\mathrm{S}}=0.853,
\end{aligned}
$$

\begin{tabular}{|c|c|c|}
\hline Entry & $\mathrm{Y}$ & $\begin{array}{l}\text { Herbicidal } \\
\text { activity }\end{array}$ \\
\hline 1 & $\mathrm{H}$ & $\mathrm{E}$ \\
\hline 2 & $3-\mathrm{Cl}$ & $\mathrm{E}$ \\
\hline 3 & $5-\mathrm{Cl}$ & B \\
\hline 4 & $5-\mathrm{Br}$ & A \\
\hline 5 & $5-\mathrm{I}$ & A \\
\hline 6 & $3,5-\mathrm{Cl}_{2}$ & A \\
\hline 7 & $3,5-\mathrm{Br}_{2}$ & A \\
\hline 8 & $3,5-\mathrm{I}_{2}$ & B \\
\hline 9 & $3,5-\mathrm{Br}, \mathrm{Cl}$ & B \\
\hline 10 & $3,5-\mathrm{Cl}, \mathrm{I}$ & $\mathrm{C}$ \\
\hline 11 & $5-\mathrm{CH}_{3}$ & $\mathrm{E}$ \\
\hline 12 & $6-\mathrm{CH}_{3}$ & $\mathrm{E}$ \\
\hline 13 & $3,5-\mathrm{CH}_{3}, \mathrm{Cl}$ & $\mathrm{C}$ \\
\hline 14 & $5,6-\mathrm{Cl}, \mathrm{CH}_{3}$ & $\mathrm{D}$ \\
\hline 15 & $5,6-\mathrm{Br}, \mathrm{CH}_{3}$ & $\mathrm{C}$ \\
\hline 16 & $3,5,6-\mathrm{Cl}_{2}, \mathrm{CH}_{3}$ & $\mathrm{E}$ \\
\hline 17 & $3,5,6-\mathrm{Br}_{2}, \mathrm{CH}_{3}$ & $\mathrm{E}$ \\
\hline 18 & $3,5,4-\mathrm{Cl}_{2}, \mathrm{CH}_{3}$ & $\mathrm{E}$ \\
\hline 19 & $3-\mathrm{CF}_{3}$ & $\mathrm{E}$ \\
\hline 20 & $5-\mathrm{CF}_{3}$ & $\mathrm{~A}$ \\
\hline 21 & $6-\mathrm{CF}_{3}$ & $\mathrm{E}$ \\
\hline 22 & $3,5-\mathrm{Cl}, \mathrm{CF}_{3}$ & A \\
\hline 23 & $5,6-\mathrm{Cl}_{1} \mathrm{CF}_{3}$ & $\mathrm{D}$ \\
\hline 24 & $3,5-\mathrm{Cl}, \mathrm{CClF}_{2}$ & $\mathrm{~A}$ \\
\hline 25 & $3,5-\mathrm{F}, \mathrm{CF}_{3}$ & A \\
\hline 26 & $3,5-\mathrm{Br}, \mathrm{CF}_{3}$ & $\mathrm{C}$ \\
\hline 27 & $5,6-\mathrm{CF}_{3}, \mathrm{~F}$ & B \\
\hline 28 & $5,6-\mathrm{CF}_{3}, \mathrm{Br}$ & $\mathrm{B}$ \\
\hline 29 & $3,5-\left(\mathrm{CF}_{3}\right)_{2}$ & $\mathrm{C}$ \\
\hline 30 & $3,5-\mathrm{NO}_{2}, \mathrm{CF}_{3}$ & $\mathrm{E}$ \\
\hline 31 & $5,6-\mathrm{CF}_{3}, \mathrm{NH}_{2}$ & $\mathrm{C}$ \\
\hline 32 & $5,6-\mathrm{CF}_{3}, \mathrm{OCH}_{3}$ & $\mathrm{E}$ \\
\hline 33 & $5-\mathrm{NO}_{2}$ & $\mathrm{E}$ \\
\hline 34 & $3,5-\left(\mathrm{NO}_{2}\right)_{2}$ & $\mathrm{E}$ \\
\hline 35 & $6-\mathrm{OCH}_{3}$ & $\mathrm{E}$ \\
\hline 36 & $3,5,6-\mathrm{Cl}_{3}$ & $\mathrm{C}$ \\
\hline 37 & $5-\mathrm{SCH}_{3}$ & $\mathrm{E}$ \\
\hline 38 & $6-\mathrm{SCH}_{3}$ & $\mathrm{E}$ \\
\hline 39 & $5-\mathrm{SOCH}_{3}$ & $\mathrm{E}$ \\
\hline 40 & $5-\mathrm{SO}_{2} \mathrm{CH}_{3}$ & $\mathrm{D}$ \\
\hline
\end{tabular}

Table 14 Change of herbicidal activity by the modification of substituents $\mathrm{Y}$ on the pyridine ring of fluazifop-ethyl $\mathbf{1 b}$.

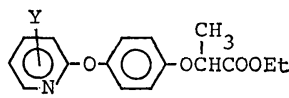

$$
R_{\mathrm{S}} \text { (leave one out) }=0.684, \pi_{\mathrm{opt}}=1.75
$$

$\left[\pi\right.$ は踈水性パラメータ, $\mathrm{B}_{4}, \mathrm{~L}$ はピリジン環の各位置 （下線を施した数值）上の置換基のステリモルパラメ 一夕] 
式（1）から最適の疎水性パラメータ $\pi$ の值により, 除草活性に極大值が存在することが理論的に示された.

以上をまとめると，ピリジニルオキシフェノキシプロ パン酸が処理された後に, 植物体内へ速やかに吸収され るためには，低級アルキルエステルの型になっているこ とが必要である（Table 11）。 また，体内での輸送過程 を経て，作用点へ到達して作用を発現する場面では，加 水分解されて遊離の酸に戻っていると想像される。

プロパン酸の $\alpha$-位の光学活性体のうち D-体のみが強 い除草活性を示し，L-体にはほとんど活性がみられない （Table 12）という事実，およびベンゼン環上の置換基 は大幅に活性を低下させる（Table 13）という結果より， 薬剤のフェノキシプロパン酸部分と, receptor が立体的 に緊密に結合している可能性が考えられる，一方，ピリ ジニルオキシ部分は分子全体の疎水性を活性発現に最適 なものにする重要な役割を担っており，フルアジホップ 扣よびそのピリジン環の 3-ハロゲン置換体は活性発現 上望ましい条件を備えているものと推測される。また， 本系統薬剤の優れた植物体内移行性には，ピリジン環窒 素の塩基性が寄与しているものと考えられる.

\section{トリフルオロメチルピリジニルオキシ基の 生理活性発現上の役割}

フルアジホップ 1 のフェノキシプロパン酸部分は, 植 物体内の受容体と相互作用をする必須部位であり，また ピリジニルオキシ基は生理活性発現上, 生体内での薬剤 の輸送に関与しているといら可能性を確認するために,
フルアジホップ ブチル 1a と，その類縁体である 3 薬 剂を用い, Table 5 に示した移行性のモデル実験を行な った結果を，Table 15 にまとめた。エーテル結合から みて para-位の置換基を塩素から，トリフルオロメチル 基に変えることによって移行性が少し改良され，ベンゼ ン環をピリジン環に置き換えることによって，大きな移 行能力が生じることがわかった. そしてトリフルオロメ チル基をピリジン環上に有するフルアジホップブチル 1a の移行は, ごく近い類縁体の中でも最大であり, ギョ ウギシバの株基部からの萌芽をも抑制した．本実験によ り,トリフルオロメチルピリジニルオキシ基の生理活性 発現上の機能は，その分子構造中の必須官能部分を標的 器官にまで輸送する能力の増強であると考えることがで きる。

\section{フルアジホップの選抜}

上述の構造活性相関研究によって，きわめて効力の高 い一群の除草剤の構造中に占める, ピリジン核の重要性 が再確認された.

Table 14 中で A ランクの活性を示した化合物につい ては，種々の屋外試験を行ない，実用効果を検討した結 果, まず, entry 6 (SL-501 エチル 9a) が選抜され, 次 いで，多年生のイネ科雑草に対する除草効力では，9a

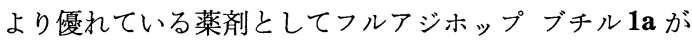
選ばれた。茎葉処理剤としての $1 \mathbf{a}$ の性能は高く評価さ れる一方で, 当時はトリフルオロメチルピリジンの経済 的合成技術の裏付けがなかったので，製造プロセスの集

Table 15 Translocation test by top treatment on C. dactylon.

\begin{tabular}{|c|c|c|c|c|c|c|c|c|c|c|c|c|c|c|}
\hline \multirow{3}{*}{$\begin{array}{l}\text { Chemicals } \\
\mathrm{X}\end{array}$} & \multirow{3}{*}{$\begin{array}{l}\text { Top } \\
\text { kill }\end{array}$} & \multicolumn{12}{|c|}{ Sprout inhibition } & \multirow{3}{*}{$\begin{array}{c}\text { Basal } \\
\text { part }\end{array}$} \\
\hline & & \multicolumn{12}{|c|}{ Nodes of stolon } & \\
\hline & & 1 & 2 & 3 & 4 & 5 & 6 & 7 & 8 & 9 & 10 & 11 & 12 & \\
\hline $\mathrm{c} 1-c$ & 8 & H & H & 世 & H & H & \# & m & W & H & m & 世 & H & 世 \\
\hline $\mathrm{CF}_{3}-\mathrm{O}$ & 10 & - & $H$ & \# & H & H & H & H & H & H & m & m & H & H \\
\hline $\mathrm{C} 1-\mathrm{O}_{\mathrm{N}}$ & 8 & - & - & - & + & + & + & + & + & $H$ & H & $H$ & H & $H$ \\
\hline $\mathrm{CF}_{3}-\mathrm{O}-$ & 10 & - & - & - & - & - & - & - & - & - & - & - & - & + \\
\hline
\end{tabular}

Top kill; 1: no effect $\sim 10$ : complete kill.

Sprout inhibition; $\#$ : no inhibition - : complete inhibition. 
中的研究が行なわれ，その結果製造上すべての問題点が 解決され，1a が上市されるに至った。

な括近年フルアジホップブチル $1 \mathrm{a}$ と同じ分野に, 次 の構造式で示すように八ロキシホップメチル15 と, キ ザロホップエチル16 が開発されているが，いずれも 9a を原点とする，アリールオキシフェノキシプロパン 酸系除草剤の範疇に位置する化合物である.

$$
z-0-0 \text { - } \stackrel{\stackrel{C}{I^{H}} \mathrm{H}_{3}}{-}
$$

\begin{tabular}{clll}
\hline $\mathrm{Z}$ & $\mathrm{R}$ & & \\
\hline & & & \\
$\mathrm{CF}_{3}-\widehat{O} \mathrm{O}_{N}^{\mathrm{C}}-$ & $\mathrm{CH}_{3}$ & ハロキシホップメチル & $\mathbf{1 5}$ \\
$u$ & $\mathrm{C}_{2} \mathrm{H}_{5}$ & キザロホップエチル & $\mathbf{1 6}$
\end{tabular}

Synthetic route 1

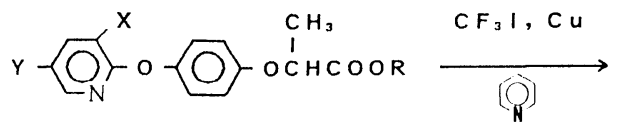

$\mathrm{Y} ; \mathrm{Br}, \mathrm{I}$

$\mathrm{R} ;$ alkyl, etc.

$\mathrm{X} ; \mathrm{H}, \mathrm{Cl}$
合 成 法

本研究の初期段階に見いだされた SL-5019 の類縁体 である５-ヨード（または 5-ブロム）ピリジニルオキシ フェノキシプロパン酸類の5位のヨウ素（または臭素） 原子を直接トリフルオロメチル基で置換する Synthetic route 1 を検討した.

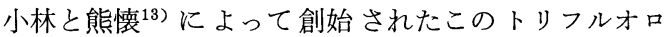
メチル化反応は，ヨウ化トリフルオロメチルを用い，銅 触媒の存在下ピリジン等の有機溶媒中で行なわれ，トリ フルオロメチル基を分子中の目的位置へ簡便に導入する 実験室的合成法として広く応用されていた ${ }^{14)}$. 本反応例 に执いては脱離する八ロゲン原子 Y がピリジン核の $\beta$ 位に結合しているため反応性は低くなっているが，硫酸 銅を亜鉛で処理して得られる活性の高い沈澱銅を触媒と して用い，溶媒のピリジンを注意深く脱水して使用する と，反応活性種としてのトリフルオロメチル-銅錯体が 効率良く生成し，目的物を得ることができた1).

一方, フルアジホップ 1 の企業化を目的として，工業的製造法が検討され，次に示す二つの合成法が開発されるに 至った.

Synthetic route 2
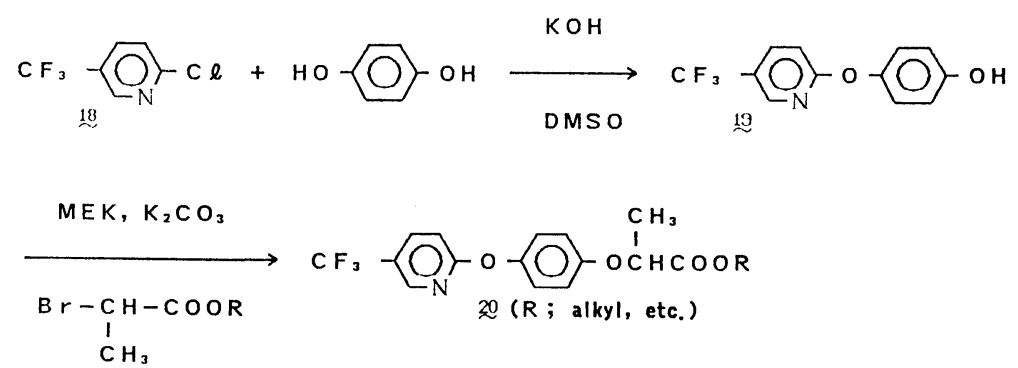

Synthetic route 3

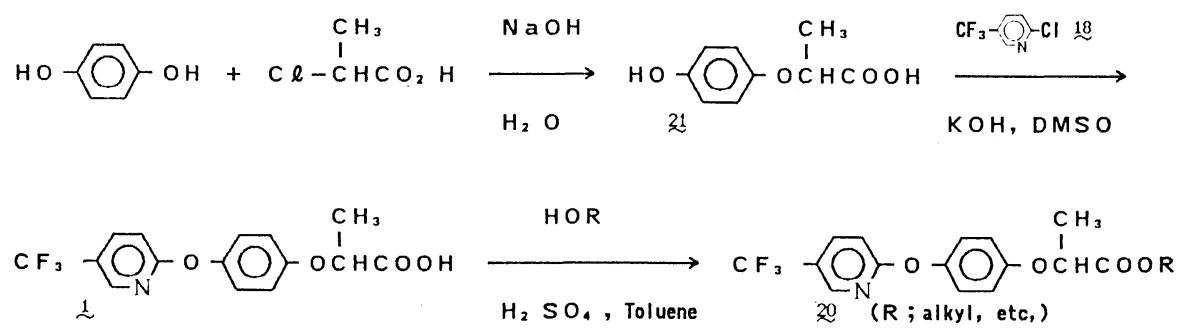


フルアジホップの開発に不可欠であって，当時工業的製造が困難視されたトリフルオロメチルピリジン中間体 18 は研究の初期段階に拈いては，2-アミノ-5-ピコリン 22 から出発し，アミノ基のジアン゙化によって 23 を，次いで 23 の側鎖メチル基の塩素化によってトリクロロ体 $\mathbf{2 4}$ を経由し，さらに 24 のフッ化アンチモン(III) によるフッ素化に よって合成された.

18 の工業的製造法としては $\beta$-ピュリンの気相での同時塩素化，フッ素化反応による製造法 ${ }^{15)}$ が当社によって開発 されている.

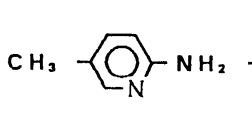

32

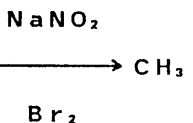

B r

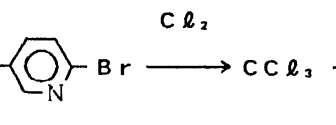

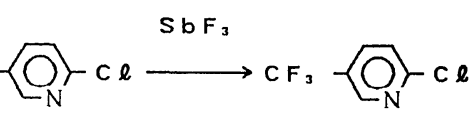

\section{おわりに}

昨今の有機合成農薬は, 標的生物には高活性を示すと ともに，非標的生物には不活性で，とくに人蓄に対する 毒性の面で，また環境に対してょり安全性の高いものへ 指向して抢り，新農薬の開発はますます難しくなってい るが，いま省みて，フルアジホップの発見（1977 年）か ら，上市 (1982 年，アルゼンチン) までが比較的速やか に行なわれたのは，除草剤の分野に拈ける当社の経験 と,フルアジホップ自身の性能が市場のニーズにマッチ していたためであろう.

本研究中でとくにトリフルオロメチルピリジニルオキ シ基の生理活性発現上の役割が解明されたが，この知見 は他の農薬分野にも応用され，除草剂以外の母核にトリ フルオロメチルピリジニルオキシ基を導入することによ り, 殺虫剤クロルフルアズロン ${ }^{16,17)}$, 殺菌剤フルアジナ ム ${ }^{18)}$ 等の興味ある農薬が著者らにより見いだされた。

$$
\mathrm{CF}_{3}
$$

フルアジホップの開発上市に当たっては社内の関係部 門の長期間にわたる開発努力に加兄，日本植調協会をは じめ, 国立および各都道府県農業研究機関の，さらに英 国 ICI 社の多大のご協力をいただきました. 関係各位に 心から感謝の意を表します。

\section{引用 文 献}

1）西山隆三・芳賀隆弘・坂下信行（石原産業）：特 公昭 58-40947 (1983)

2) K. Fujikawa, K. Kondo, I. Yokomichi, F. Kimura, T. Haga \& R. Nishiyama: Agric. Boil. Chem. 34, 68 (1970)

3）西山隆三・藤川敢市・横道 勲 (石原産業)：特 公昭 49-826 (1974)

4) 未発表

5）高橋量平・藤川敢市・横道 勲 ・土岐忠昭 ・ 染谷 進三 (石原産業)：特公昭 48-80726 (1973)

6) 高橋量平・藤川敢市・横道 勲 - 染谷進三 - 坂下 信行 (石原産業)：特公昭 51-12924 (1976)

7）高橋量平 ・藤川敢市 - 横道 勲 - 辻井康弘 - 坂下 信行 (石原産業)：特開昭 51-48432 (1976)

8）木村史雄 - 坂下信行 - 本多千元：植物の化学調節 17, $170(1982)$

9) L. G. Holm, D. L. Plucknett, J. V. Pancho \& J. P. Herberger: "The World's Worst Weeds," The University Press of Hawaii, Honolulu, 1977

10）吉井 博 - 本多千元・坂下信行 - 木村史雄：日本 雑草学会第 23 回講演会講演要旨集, p. 11, 1983

11）吉井 博 - 本多千元・坂下信行 - 木村史雄：日本 農薬学会第 11 回大会講演要旨集, p. 42,1986

12）芳賀隆弘・藤川敢市・坂下信行・西山隆三：農薬 誌 10, 111 (1985)

13) Y. Kobayashi \& I. Kumadaki: Tetrahedron Lett. 1969, 4095

14）細川研三・犬飼 鑑：日本化学会誌 1976, 1791

15）西山隆三・藤川敢市・横道 勲 - 辻井康弘 - 西村 重幸（石原産業）：特開昭 55-120564（1980）

16) T. Haga, T. Toki, T. Koyanagi \& R. Nishiyama: Abstr. 5th Int. Congr. Pestic. Chem. (IUPAC), IId-7, 1982

17）芳賀隆弘・土岐忠昭 - 小柳 徹 - 西山隆三：農薬 誌 10, 61 (1985)

18）西山隆三・藤川敢市・芳賀隆弘 - 土岐忠昭 - 長谷 邦昭 - 今井 修 (石原産業)：特開昭 56-92272 (1981) 